Ann. Biol. anim. Bioch. Biophy's, I975, 15 (2), 28I-29o.

\title{
THE USE OF PROGESTOGENS IN CATTLE UNDER TROPICAL OR SUBTROPICAL CONDITIONS
}

\author{
W. JÖCHLE \\ International V'eterinary Section, Syntex Research, \\ Division of Syntex Corporation, 3401 Hillview Avenue, \\ Palo Alto, California, 94304 (L. S. A.)
}

\begin{abstract}
SUMMARY
The cattle industry in the tropics and subtropics is predominantly beef producing industry, using Zebu (Bos indicus) or Zebu-crossbreds in many local varieties. Their productivity is low and their reproduction often slow ; for improvement, artificial insemination (AI) would be desirable, for which cycle synchronization is a prerequisite.

Chlormadinone acetate (CAP) has been tested successfully in Mexico, Guatemala and Tanzania for its cycle synchronizing capabilities under prevailing ranch conditions. Dose levels and dosing regimes, adapted from experiences in European cattle (Bos taurus), were found to be effective. Oral application for 15 days or combinations of injections and short oral feeding periods, commencing Io or 12 days later, were used. Besides good synchronization, a marked therapeutic effect on animals showing functional anestrus was observed. Although pregnancy rates from AI at first estrus were often but not always low, pregnancy rates from two or three inseminations often surpassed those in controls significantly. Management excerted significant effects on the successful use of cycle synchronization and $\mathrm{AI}$. In European cattle (beef and dairy) treated in the tropics, effectiveness of CAP for cycle control and therapy of infertility was unaffected by climatic conditions.
\end{abstract}

\section{INTRODUCTION}

In the developing countries in the tropies and subtropics, ranch cattle industry is, or will become, an important part of the national economy. This industry relies nearly exclusively on Zebu breeds (Bos indicus) and crossbreeds with European breeds (Bos taurus), due to their specific adaptation to climatic conditions and their resistance to tropical disease. Disadvantages of these breeds or crosses seem to be their low productivity : they seem to mature late, and show prolonged post-partal anestrus, resulting in calving intervals of up to 24 months. In addition, adherence to a spring breeding season has been reported (JöchLE, I972a, b). Food for cattle in these countries is mostly restricted to pasture which, if not cultivated, 
fertilized and/or irrigated and supplemented, provides a seasonal cyclic pattern from optimal to fair to minimal supply. Low productivity more often than not results from the interaction of genetic traits, poor nutrition, and inadequate management (record keeping; culling; supply of missing minerals, trace elements, energy; disease and parasite control).

In this setting, cycle synchronization in general serves a multitude of purposes :

I. Its employment is a prerequisite for the widespread use of artificial insemination, and therefore an essential tool for genetic upgrading.

2. It is a means to breed as many animals as possible during the height of their fertility season, including heifers and lactating cows.

3. It should allow to shift, if necessary, breeding and calving season to coincide with the seasonal optimal climatic and environmental conditions; ideally, purpose 2 and 3 should coincide.

4. It could become the focus by which overall managerial standards within herds are lifted to levels which make the use of cycle synchronization and artificial insemination effective, predictable and economically attractive.

With these goals in mind, large field trials were organized in Mexico (1968-1971), in the tropical Gulf Coast region (I9 ${ }^{\circ} 0^{\prime}$ to $22^{\circ} 10^{\prime} \mathrm{N}$ ) (HIDALGO and JöchLE, I972 ; HIdALgo et al., I972; Jöchle et al., I973), and from I969 to I97I in Tanzania $\left(3^{\circ} \mathrm{S}\right.$ ), in the highlands (Schmid et al., I973), as well as the coastal areas (MACFARLANE and SALEKA, I97I). Since to my knowledge no other studies of a similar size and intent in the tropics have been published, conclusions and recommendations are based exclusively on the results obtained in our studies.

\title{
MATERIAL AND METHOD
}

\begin{abstract}
Animals
T. Mexico.

A total of 824 animals (6I 7 purebred Zebu (Brahman type), rog crossbreds and 89 Charolais) were treated for cycle synchronization; 280 animals (I 7 I purebred Brahmans, Io9 crossbreds) served as controls. Artificial insemination was used in all animals, with deep-frozen semen from Brahman and Zebu bulls with known fertility. All animals were observed for heat twice daily; treated animals were inseminated once at the first and second heat after synchronization; controls were inseminated once at any heat between Day $\mathbf{I}$ of the treatment schedule and during the next 45 days. Thereafter, observations and inseminations ceased.

All purebred animals were kept on irrigated Pangola Grass pasture and received supplements, while crossbreds were grazed on Guinea Grass and were not supplemented. Due to the distinct breeding season in this area (JöchLE, I972 $a, b$ ), trials were restricted to the months of February to July. All pregnancies were confirmed by rectal palpation
\end{abstract}

\section{Tanzania.}

In the highland studies, 580 indigenous Zebu cattle (Tanganyika Shorthorn and Boran) and ${ }_{6} 6_{3}$ European dairy cattle (mostly Holstein) were treated, and 445 indigenous Zebus served as controls.

In the coastal trial, 63 indigenous maiden heifers (Boran $\times$ Sahiwal) were used.

All animals were kept on pasture and did not receive supplements. Pasture conditions at the highland varied between seasons; drought reduced food supply temporarily. Twice daily, animals were observed for heat, and either inseminated once (coastal and most highland studies) or serviced naturally (see tables 3 and 5), for two heat periods after treatment, or during 24 days in the controls. All pregnancies were confirmed by rectal palpation. 


\section{Treatments}

The progestogen used in all trials was chlormadinone acetate (CAP). The following treatment schedules were used :

\section{Mexico.}

Unpublished trials confirmed that oral application of $10 \mathrm{mg}$ CAP/animal/day, for 14 days, resulted in good inhibition of estrus and ovulation, and synchronization as well. This dose was adapted for our trials; it was applied in approximately 400 to $500 \mathrm{~g}$ of raw sugar to heifers and cows (dry and lactating), most of them cycling. In one trial, a $5 \mathrm{mg}$ daily dose was used (see table $\mathbf{I}$ ).

\section{Tanzania.} and 4 ).

Following these leads, Io mg CAP were used orally in capsules, for 14 or 18 days (see tables 3

A simplification of CAP administration was explored by applying $50 \mathrm{mg}$ CAP in oily solution, followed by an oral administration of ro $\mathrm{mg}$ CAP daily (in a capsule) from Days 9 to I2, or I I to I5, after injection. These schedules were supplemented by giving estradiol valerate (EV) together with the CAP injection; or mestranol (ME), ro $\mathrm{mg}$ oral daily, together with CAP from Day I I to 15 ; or HCG, given 60 hours after the last oral CAP administration, with two inseminations 12 and 24 hours later (table 5).

\section{RESULTS}

$$
\text { I. - Mexico }
$$

A summary of all trials is shown in table $\mathrm{I}$. The degree of synchronization is presented in figure $\mathbf{I}$.

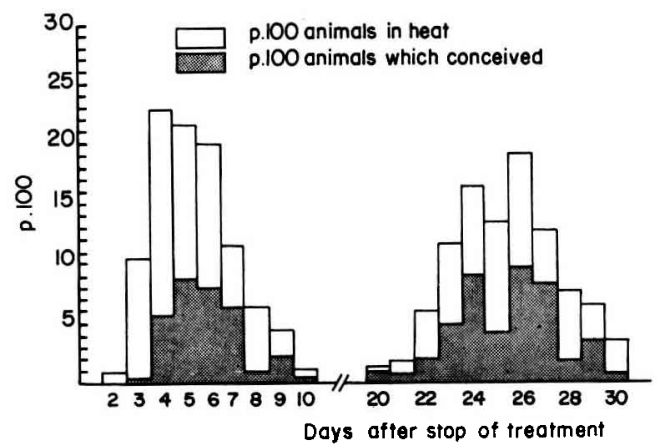

FIG. I. - Distribution of heat presentations and conception after oral administration of $10 \mathrm{mg} \mathrm{CAP}$ over all treatments $(n=668)$

In general, a satisfactory degree of synchronization has been achieved, with a " hold-over " effect to the second heat period which was still reasonably well synchronized. The low percentage of animals showing synchronized heat after treatment has to be compared with the percentage of cycling animals in the control population, and reflects the varying degrees of anestrus prevailing. Conceptions at the first synchronized heat were somewhat, but in individual trials never significantly lower than in the controls. At the second, still sufficiently synchronized, heat conceptions were unimpaired. Conceptions at first and second heat, in comparison with 
the overall conception rate in controls, did not reveal any differences. Pregnancy rate after two inseminations indicated no reduction of estrus presentation or fertility after treatment.

\section{TABLE I}

Cycle synchronization and conception rates with $C A P, 10$ (or 5 ) $m g$ for 14 days, in Bos indicus (Brahman), Bos taurus (Charolais) and crossbred cattle in the tropics.

(Trials 3 and 4 are not included in summary $\mathbf{I}$ )

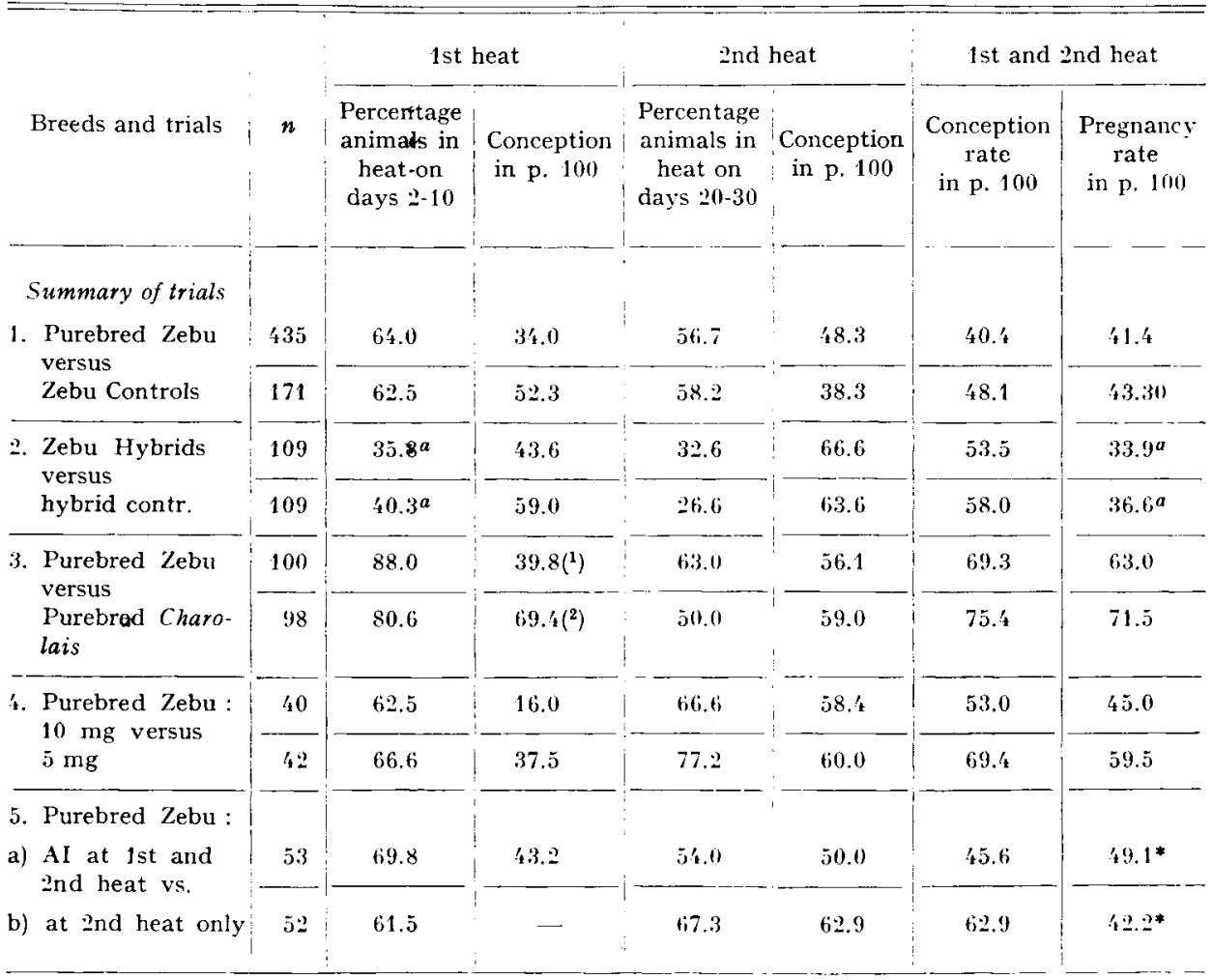

* difference not significant : $\left({ }^{1}\right)$ vs. $\left({ }^{2}\right)=p<0.001 ; a$ : poor management, high anoestrus rate.

The low fertility at the first, but the good fertility at the second still synchronized heat, led to a trial in which insemination at the first and second heat was compared with insemination at the second heat only. Table I (group 5) summarizes this trial. Differences in the overall pregnancy rate were not significant.

When a group of purebred Charolais heifers, adapted to the tropics by active anaplasmosis immunization sprocedures, were synchronized simultaneously with the Zebu heifer population in the same environment, an unusually high conception rate was achieved in the Charolais population (table I). In Charolais, the synchronized heat occured earlier (79.5 p. Ioo animals showing heat between Day 2 and 5 versus 31.8 p. Ioo in Zebu). 
TABLE 2

Infuence of management (A), phase of reproduction (B) and psychosexual stimulation (C) on oestrus cycle synchronization in zebu cattle in the tropics

\begin{tabular}{|c|c|c|c|c|c|c|c|}
\hline \multirow{2}{*}{$\begin{array}{l}\text { Trials and } \\
\text { conditions } \\
\text { influencing } \\
\text { synchroni- } \\
\text { zation }\end{array}$} & \multirow[b]{2}{*}{$n$} & \multicolumn{2}{|c|}{ 1st heat } & \multicolumn{2}{|c|}{ Ind heat } & 1 st and & and heat \\
\hline & & $\begin{array}{l}\text { Percentage } \\
\text { animals in } \\
\text { heat on days } \\
\qquad .10\end{array}$ & $\begin{array}{l}\text { Conception } \\
\text { in p. } 100\end{array}$ & $\begin{array}{c}\text { Percentage } \\
\text { animals in } \\
\text { heat on days } \\
\quad \mathbf{2 0 - 3 0}\end{array}$ & $\begin{array}{l}\text { Conception } \\
\text { in p. } 100\end{array}$ & $\begin{array}{c}\text { Conception } \\
\text { rate } \\
\text { in p. } 100\end{array}$ & $\begin{array}{c}\text { Pregnancy } \\
\text { rate } \\
\text { in p. } 100\end{array}$ \\
\hline
\end{tabular}

A. Management : Insufficient management (A) vs. improved management (B)

\begin{tabular}{|c|c|c|}
\hline 1) & $\begin{array}{l}\text { Purebred } \\
\text { Zebu (A) }\end{array}$ & 154 \\
\hline & $\begin{array}{l}\text { Zebu con-i } \\
\text { trols (A) }\end{array}$ & 137 \\
\hline \multirow[t]{2}{*}{ 2) } & $\begin{array}{l}\text { Purebred } \\
\text { Zebu (B) }\end{array}$ & 281 \\
\hline & $\begin{array}{l}\text { Zebu con- } \\
\text { trols (B) }\end{array}$ & 34 \\
\hline \multirow[t]{2}{*}{ 3) } & $\begin{array}{l}\text { Zebu } \quad \overline{h y-} \\
\text { brids (A) }\end{array}$ & 109 \\
\hline & $\begin{array}{l}\text { Hybrid } \\
\text { cont. (A) }\end{array}$ & 109 \\
\hline
\end{tabular}

$\begin{array}{r}67.5 \\ \hline 56.3 \\ \hline\end{array}$

\begin{tabular}{l:c}
\hline $15.7^{a}$ & 54.4 \\
\hdashline 40.3 & 35.0 \\
\hline $47.9^{b}$ & 58.9 \\
\hline-50.0 & 58.0 \\
-43.6 & 32.6 \\
\hline$-\frac{26.6}{59.0}$
\end{tabular}

$\frac{50.6}{38.9} \frac{46.7}{36.5}$

\begin{tabular}{l|l}
\hline 30.2 & $35.1^{c}$ \\
\hline-39.8 & $32: 8^{a}$ \\
\hline 46.4 & $44.9^{d}$ \\
\hline 46.4 & $55.9^{b}$ \\
\hline 53.5 & 33.9 \\
\hline 58.0 & $36.6^{-6}$ \\
\hline-7
\end{tabular}

B. Phase of reproductive life

\begin{tabular}{|c|c|c|c|c|c|c|c|c|}
\hline 1) & $\begin{array}{l}\text { Dry cows, } \\
\text { mostly } \\
\text { cycling }\end{array}$ & 64 & 76.5 & 46.95 & 73.1 & 30.0 & 40.5 & 50.0 \\
\hline 2) & $\begin{array}{l}\text { Lact. cows } \\
\text { high an- } \\
\text { oestrus }\end{array}$ & 12 & 38.2 & 45.50 & 40.5 & $\$ 0.0$ & 42.2 & 26.2 \\
\hline 3) & $\begin{array}{l}\text { Heifers, } \\
\text { ca. } 50 \text { p. } 100 \\
\text { cycling }\end{array}$ & 35 & 45.7 & 55.2 & 6.5 .4 & 35.3 & 42.9 & 42.9 \\
\hline
\end{tabular}

C. Psychosexual stimulation: Herd with bulls (I) or without bulls (II)

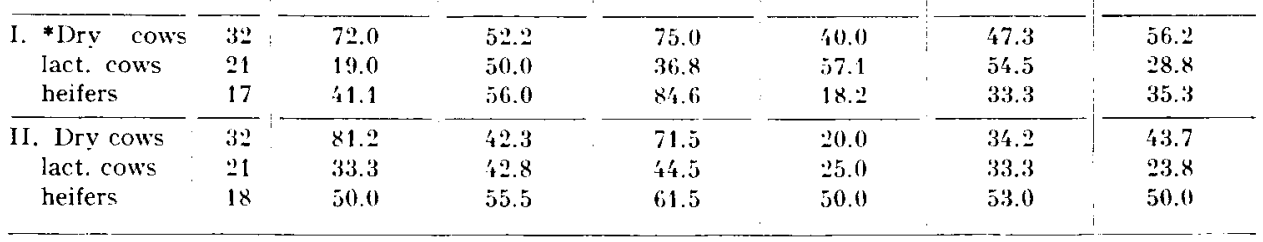

* Animals constantly exposed to 3 sexually active, entire bulls with translocated penis.

\section{Statistic to table 1:}

A. Management : $a$ versus $b=p<0.001$

$$
c \text { versus } d=p<0.01
$$

13. Phase of reproduction : Group 1 versus (roup $:: p<0.01$

Group 2 versus Group 3:p<0.01

Group 2 versus Group 1 and $3: p<0.001$

C. Psychosexual stimulation: None of the differences between I and II or of their groups 1 to 3 are significant. 
CAP dose reduction to $5 \mathrm{mg}$ shortened intervals between last medication and synchronized heat (heat presentation between Day 2 and $5=85.8 \mathrm{p}$. Ioo versus $44 \mathrm{p}$. IoO in the Io $\mathrm{mg}$ group), but had no influence on fertility and did not seem to always control heat symptoms during the synchronization period sufficiently.

Management conditions, as defined above, exerted strong influences on the overall outcome of synchronization trials, as shown in table 2. Poor management resulted in significantly reduced conception and pregnancy rates. Under those conditions, CAP may have a marked estrus inducing effect, but can certainly not overcome fertility reducing obstacles provided by insufficient management conditions.

In an investigation into influences resulting from the phase of reproductive life (a comparison of the synchronization effect of CAP in cycling dry cows, mostly non-cycling lactating cows, and partially cycling heifers) revealed strong interferences with the outcome of cycle synchronization : synchronization and pregnancy rates were significantly different between groups, reflecting strongly the number of animals already cycling before treatment. Conception rates of those animals responding to treatment with synchronized heat were almost identical. Already cycling animals were almost totally synchronized, whereas in non-cycling animals any estrus promoting effect of CAP was insufficient to overcome estrus preventing forces oparating during the early post-partum phase in lactating Zebu cows (table 2).

In a small trial on psychosexual stimuli, no significant effects were exerted to a mixed population of dry or lactating cows and heifers by the presence or absence of bulls (with deviated penis) ; there was no influence on the overall synchronization effect as well as the results subdivided in dry or lactating cows or heifers. There was an obvious lack of stimulation in lactating cows, where this effect would have been most desirable, and in heifers as well (table 2).

\section{2. - Tanzania}

\section{a) Oral application of $C A P$.}

Tables 3 and 4 summarize all trials; figure 2 presents the degree of synchronization achieved in the highland studies. A good degree of synchronization was recorded ; in the Tanga trial, an I8-day treatment period seemed to give more precision and not less fertility, if compared with the $\mathrm{I}_{4}$-day treatment regime. Estrus presentation and overall pregnancy rate was generally higher in the treated population, reaching significance in the Zebu herds.

\section{b) Combination treatment.}

The same observation holds true for this method by which the total amount of drug and labor involved in application is reduced by about 33 and $60 \mathrm{p}$. Ioo. Any additional treatment (EV, ME, or $\mathrm{HCG}$ ) were virtually without any benefitial effect (table 5). Striking was again the estrus inducing effect of CAP. Natural insemination in general, but not always, was superior in its effects to artificial insemination. 
TABLE 3

Cycle synchronization with CAP in Tanzania: Indigenous Zebu and Furopean cattle Summary of all trials in which Io $\mathrm{mg}$ CAP/animal/day were given orally for $\mathrm{I}_{4}$ days

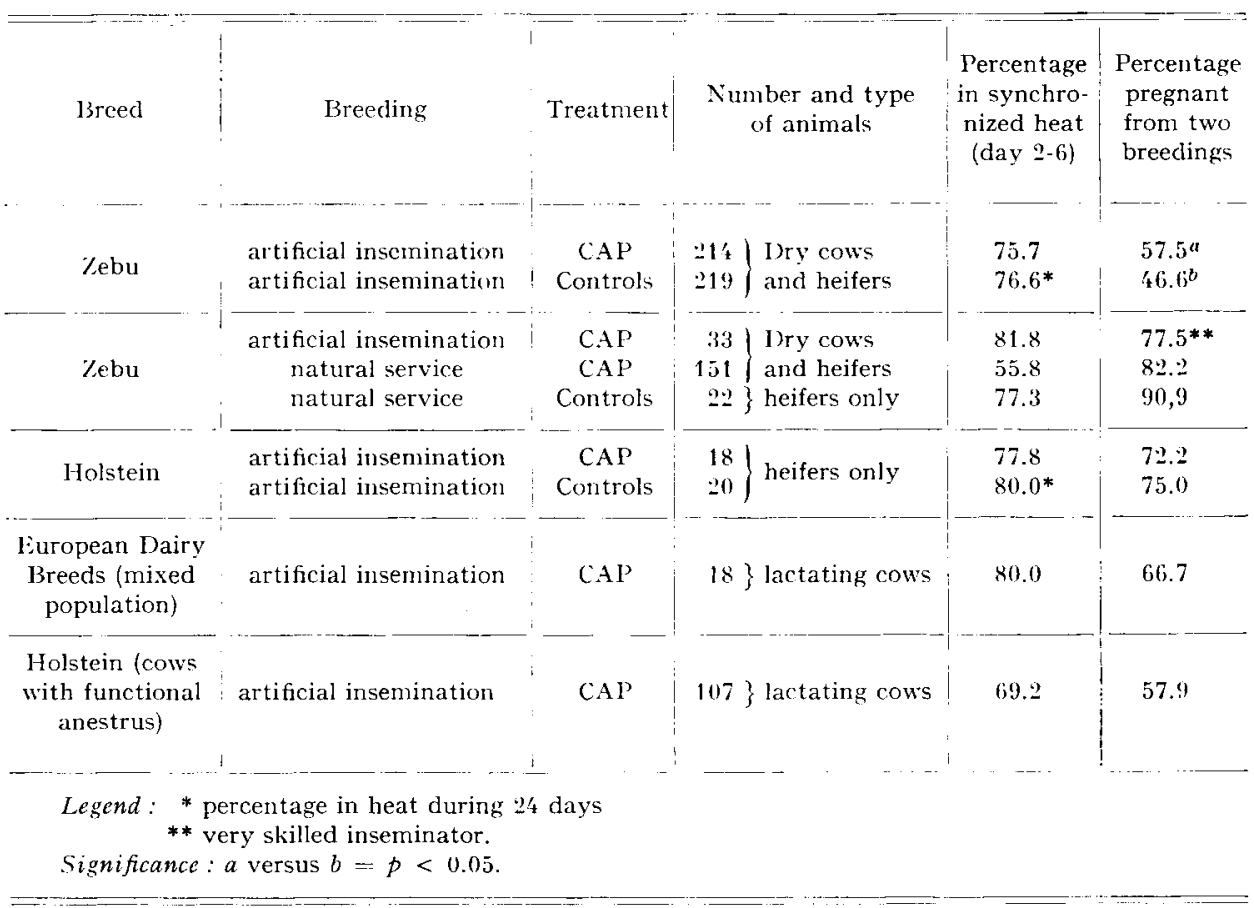

TABLE 4

Post-CAP conception rate

(CAP for cycle control in indigenous Zebu heifers in Tanzania/coastal region)

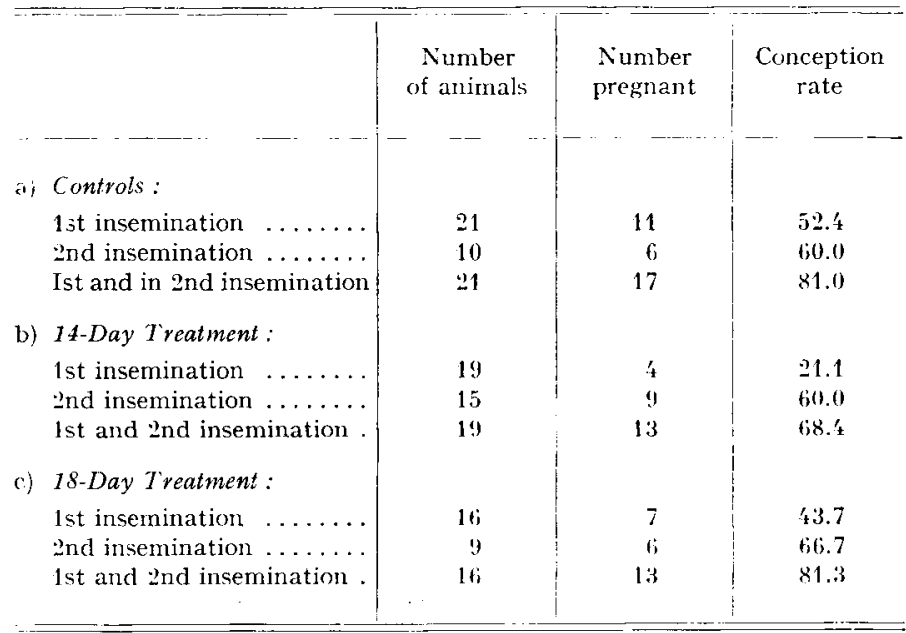




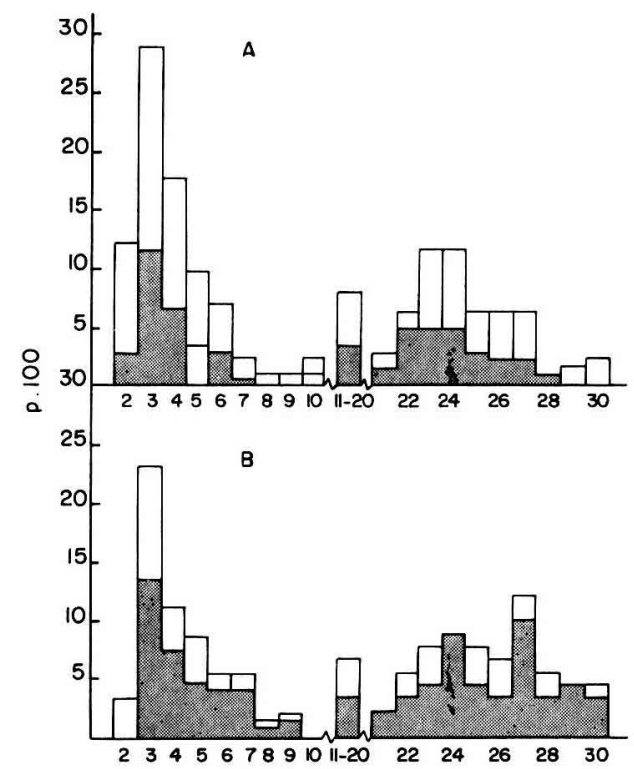

FIG. 2. - Distribution of heat presentations and conceptions after oral admintistration of $10 \mathrm{mg} \mathrm{CAP}$ daily for 14 days :

(A) in 214 animals which were artificially inseminated (I969-1970):

(B) in 151 animals which weve seved naturally (I970)

口, p. Ioo animals in heat; $\mathbf{m , p . ~ I o o ~ a n i m a l s ~ w h i c h ~ c o n c e i v e d ~}$

TABLE 5

Cycle synchronization with CAP in Tanzania in indigenous Zebu cattle

Summary of all trials with CAP injected (50 mg),

followed with CAP given orally (Io mg/day) from either Day 9-1 2 or Day I I-I 5, after injection

\begin{tabular}{|c|c|c|c|c|c|}
\hline \multirow[b]{2}{*}{ Breeding } & \multirow[b]{2}{*}{ Treatment } & \multirow{2}{*}{$\begin{array}{c}\text { Number and type } \\
\text { of animals }\end{array}$} & \multicolumn{2}{|c|}{ Percentage in synchronized } & \multirow{2}{*}{$\begin{array}{l}\text { Percentage } \\
\text { pregnant from } \\
\text { two breedings }\end{array}$} \\
\hline & & & $\begin{array}{l}\text { 1st heat } \\
(\text { day }-6)\end{array}$ & $\begin{array}{c}\text { 2nd heat } \\
\text { (day } \geq 1-27)\end{array}$ & \\
\hline \multirow{3}{*}{$\begin{array}{l}\text { Natural service } \\
\text { Natural service } \\
\text { Natural service }\end{array}$} & $\mathrm{CAP}$ & \multirow{3}{*}{ 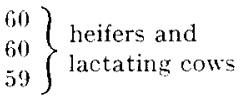 } & 36.7 & 57.9 & 88.0 \\
\hline & $\mathrm{CAP} \perp \mathrm{EV}$ & & 36.7 & 75.0 & 71.6 \\
\hline & Controls & & 47.5 & $z$ & $57.6^{2}$ \\
\hline \multirow{2}{*}{$\begin{array}{c}\text { Artificial } \\
\text { insemination }\end{array}$} & $\mathrm{CAP}^{2}$ & \multirow{2}{*}{$\left.\begin{array}{l}68 \\
79\end{array}\right\} \begin{array}{l}\text { heifers and } \\
\text { dry cows }\end{array}$} & 5.3 .0 & 36.4 & $58.8^{4}$ \\
\hline & Controls & & 38.9 & $?$ & $13.0^{b}$ \\
\hline \multirow{3}{*}{$\begin{array}{c}\text { Artificial } \\
\text { insemination }\end{array}$} & CAP & \multirow{3}{*}{$\left.\begin{array}{l}41 \\
41 \\
41\end{array}\right\}$ lactating cows } & 49.0 & 29.4 & $26.66^{a}$ \\
\hline & $\mathrm{CAP}+\mathrm{ME}$ & & 88.9 & $5: 3.0$ & $29.3^{a}$ \\
\hline & Controls & & 26.8 & 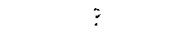 & $1 . x^{b}$ \\
\hline \multirow{3}{*}{$\begin{array}{l}\text { Artificial } \\
\text { insemination }\end{array}$} & CAP & \multirow{3}{*}{$\left.\begin{array}{l}36 \\
25 \\
44\end{array}\right\}$ dry cows } & 63.2 & 40.0 & $6 \times .5^{a}$ \\
\hline & $\mathrm{CAP}+\mathrm{HCG}$ & & 28.0 & $4+4$ & $6^{\prime}+0^{a}$ \\
\hline & Controls & & 40.9 & $\bar{z}$ & $15.5^{b}$ \\
\hline
\end{tabular}

Significance : $a$ versus $b=p<0.01$.

Additional treatments : $\quad \mathrm{EV}=$ estradiol valerate, $5 \mathrm{mg}$ injected simultaneously with $\mathrm{CAP}$; $\mathrm{ME}=$ mestranol, $10 \mathrm{mg}$ given orally simultaneously with CAP (day 11-15) : HCG $=1000 \mathrm{IU}$ applied $60 \mathrm{~h}$ after last oral CAP medication. 


\title{
DISCUSSION
}

A progestogen (CAP) administered by various means of application, provided a reliable method of cycle synchronization in the tropics, allowing the employment of artificial insemination at the wanted season, and increased the number of cattle bred at both theaters of operation.

Disadvantages were the labor intensive treatment schedules, although methods have been developed to reduce this workload considerably without jeopardizing effects. Advantages of oral administration methods are training effects, teaching these animals to be approached and touched by man, a preparation essential for the technical act of artificial insemination to follow. When these animals have learned to take man-given food, supplements can be added as well as energy. At the same time, animals can be subjected to any kind of therapeutic treatments.

The greatest advantage for the use of progestogens in general under tropical ranch conditions seems to be a therapeutic effect overcoming the high anestrus rate prevailing under those management conditions. Similar effects for the progestogen CAP in European cattle have been reported and summarized earlier (GÜNZLER and JöchlE, I973; JöCHLE, I969). New supportive data in this respect have been published for European dairy cattle (JöChlE, I969; KoRDTs et al., I974) or primitive beef type breeds (Santisteban Garcia and Sanz Parejo, r973) and were brought to our attention for European and Zebu cattle (ACORD and FOOTE, I974; McFarlanE and MNDOLWA, I972). Although cycle synchronization with progestogens should never be used as a substitute for insufficient herd managment, its employment as an effort to improve herd management seems to offer more rewards than originally anticipated.

Colloque : Control of sexual cycles in domestic animals October 27-30, 1974, Nouzilly.

\section{ACKNOWLEDGEMENTS}

The studies reported here were made possible by the co-operation and collaboration of Drs M. A. Hidalgo, T. Gimenez and R. Garcia, Mexico, D. F. ; Drs D. Smidt and H. Schmidt, Göttingen ; and J. S. Macfarlane, Dar-es-Salaam, Tanzania.

\section{RÉSUMÉ}

\author{
UTILISATION DES PROGESTAGŶ̀NES CHEZ LES BOVINS \\ PLACÉS EN CONDITIONS TROPICAIES ET SUBTROPICALES
}

L'élevage bovin sous les tropiques et au voisinage des tropiques est surtout orienté vers la production de viande en utilisant les zebus (Bos indicus) ou des croisements zebus $\times$ races locales. Leur productivité est faible et leur reproduction lente. Pour les améliorer, l'J A serait souhaitable, le contrôle du cycle est un préalable. 
L'acétate de chlormadinone (CAP) a été essayé avec succès à Mexico, au Guatemala et en Tanzanie du point de vue de son pouvoir de synchronisation en conditions de ranch. Les doses et les régions des traitements, adaptés des expériences faites chez les bovins européens (Bos taurus), ont été trouvées efficaces. Une administration orale pendant $\mathrm{I}_{5}$ jours ou des combinaisons d'injections et de périodes courtes de traitement oral commençant ıo à I 2 jours plus tard étaient utilisées. Outre une bonne synchronisation, un effet thérapeutique marqué chez les animaux en anœstrus était observé. Bien que les taux de gestation à partir de l'IA au premier œstrus soient souvent mais pas toujours bas, les taux de gestation après une ou deux inséminations dépassaient souvent ceux des témoins de façon significative. Le mode d'élevage exerce des effets significatifs sur le succès de la synchronisation et de l'IA chez les bovins européens (viande et lait) traités sous les tropiques. L'efficacité du CAP pour le contrôle du cycle et la thérapeutique de l'infertilité n'était pas affectée par les conditions climatiques.

\section{REFERENCES}

Acord C. R., Foote W. C., I974. The influence of chlormadinone acetate (CAP) treatment and increased energy intake on calving rate in commercial cattle under range conditions (in preparation).

Günzler O., Jöchle W., I973. Progestin use in cattle infertility. (Unusual cases : Clinical report No I). Zuchtygiene, 8, I7I-I 74 .

Hidalgo M. A., Jöchle W., 1972. Oestrous cycle synchronization in beef cattle (Bos taurus and indicus) under tropical ranch conditions. Proc. VII Int. Congr. Anim. Reprod. Artif. Insem., II, 875.

Hrdalgo M. A., Gimenez T., Jöchle W., I972. Influence of management, phase of reproductive life and psychosexual stimulation on oestrus cycle synchronization in Zebu cattle in the tropics. Proc. VII Int. Congr. Anim. Reprod. Artif. Insem., III, I 757.

Jöchle W., I969. Anwendung der Gestagene in Veterinärmedizin und Zootechnik. Kap. XII, Handbuch d. exp. Pharmakologie, Bd XXII/2, 606-7I9.

Jöchle W., r972 a. Seasonal reproductive functions in Zebu cattle. Int. J. Biometeor. 16, I3I-I44.

Jöchle W., r972 b. Seasonal influences on reproductive patterns in Zebu and Zebu crossbred cattle in the tropics. Proc. VII Int. Congr. Anim. Reprod. Artif. Insem., III, 2026-2030.

Jöchle : W., Hidalgo M. A., Gimenez T., Garcia R. C., 1973. Oestrus cycle synchronization in Zebu cattle and its use in cattle production and management in the tropics. J. Agric.Sci., 80, 329-340.

Kordts E., Jöchle W., Kaltschitsch K., I974. Prophylactic effect of a progestin (chlormadinone acetate : CAP) on fertility of dairy cows after post-partum use. Theriogenology, 1, r69-176.

Macfarlane S. J., Saleka R., I97I. Synchronization of oestrus and ovulation in Bos indicus heifers using an orally active progesterone. E. Afr. Agric. Forestry J., 36, 353.

Macfarlane S. J., Mndolwa J., I972. The effect of an orally active progestogen (CAP) on anoestrus in cattle (unpublished).

Santisteban Garcia F., Sanz Parejo J., r973. Sincronizacion de celo y tratamiento conceptiro en ganado vacuno braro. Archivos de zootecnia, 21, 203.

Schmidt H., Sмidt D., Jöchle W., r973. Oestrus cycle synchronization and oestrus induction in indigenous and European cattle in Tanzania. J. Agric. Sci., 81, $381-389$. 